\title{
Application of Mental Nursing Care on Ny. N With Impaired Sensory Perception: Visual Hallucinations
}

\section{Mega Oktafia Sianturi}

\author{
Megasianturi96@gmail.com
}

\section{BAB 1}

\section{PENDAHULUAN}

\subsection{Latar Belakang}

Skizofrenia merupakan sekelompok reaksi psikotik yang mempengaruhi berbagai area fungsi individu, termasuk berfikir, berkomunikasi, merasakan dan menunjukkan emosi serta gangguan otak yang ditandai dengan pikiran kacau, waham, halusinasi, dan perilaku aneh (Pardede, 2019). Skizofrenia merupakan gangguan mental berat dan kronis yang menyerang 20 juta orang di seluruh dunia didapatkan bahwa prevalensi penderita skizofrenia di Indonesia sebesar 1,8 per 1000 penduduk. Hasil survey awal yang dilakukan di poliklinik rawat jalan RSJ Medan di temukan sebanyak 13.899 pasien yang rawat jalan dibawa oleh keluarganya untuk berobat Penderita skizofrenia yang sembuh dikembalikan kepada keluarga untuk dirawat dirumah. Keluarga adalah orang yang dekat dengan pasien harusbertanggung jawab dalam merawat pasien, namun dalam pelaksanaannyahal ini menjadi beban bagi keluarga. Keadaan ini meningkatkan stres dalam keluarga (Pardede, Harjuliska \& Ramadia, 2021).

Merawat pasien skizofrenia dengan masalah halusinasi dibutuhkan pengetahuan, keterampilan dan kesabaran serta dibutuhkan waktu yang lama akibat kronisnya penyakit ini. Anggota keluarga yang bersama pasien skizofrenia menghabiskan lebih banyak waktu di rumah untuk merawat yang sakit dari pada memperhatikan dan mengurusi dirinya. Kemampuan dalam merawat pasien skizofrenia merupakan keterampilan yang harus praktis 
sehingga membantu keluarga dengan kondisi tertentu dalam pencapaian kehidupan yang lebih mandiri dan menyenangkan (Pardede, 2020).

Jumlah penderita gangguan jiwa dunia adalah 450 juta penduduk, memperkirakan 51 juta penduduk Amerika terdiagnosis gangguan jiwa dan dari jumlah tersebut, 6.5 juta pasien mengalami disabilitas akibat gangguan jiwa berat yang dialaminya. Di Indonesia sendiri, prevalensi terjadinya gangguan jiwa adalah sebesar $0.5 \%$ dari jumlah penduduk Indonesia. Sedangkan prevalensi Gangguan Mental Emosional adalah 11,6\% pada penduduk yang berumur lebih dari 15 tahun keatas. Jumlah penderita gangguan jiwa ini akan semakin bertambah seiring dengan terjadinya krisis multidimensi maupun bencana yang terjadi di Indonesia (Daulay \& Wahyuni, 2020).

Halusinasi adalah salah satu gejala gangguan jiwa pada individu yang ditandai dengan perubahan sensori persepsi, merasakan sensasi palsu berupa suara, penglihatan, pengecapan, peraba atau penghidu. halusinasi merupakan salah satu gejala gangguan jiwa yang pasien mengalami perubahan sensori persepsi, serta merasakan sesnsasi palsu berupa suara, penglihatan, pengecapan, perabaan atau penciuman. Pasien merasakan stimulus yang sebenarnya tidak ada. Pasien gangguan jiwa mengalami perubahan dalam hal orientasi realistis. Salah satu manifestasi yang muncul adalah halusinasi yang membuat pasien tidak dapat menjalankan pemenuhan dalam kehidupan sehari (Erliyani, 2019).

Halusinasi yang muncul pada individu yang mengalami perlu dikontrol agar klien mampu kembali dalam kondisi realita yang sebenarnya. Halusinasi yang tidak di kontrol dapat berakibat individu mengalami kegagalan dalam mengenali realitas dan jatuh pada kondisi halusinasi yang semakin parah (Prakoso \& Herliawati, 2020). Survei awal dilakukan di Yayasan Pemenang Jiwa Sumatera dengan jumlah pasien 75 orang tetapi yang menjadi subjek di dalam pembuatan askep ini berjumlah 1 orang dengan pasien masah halusinasi penglihatan atas nama inisial Ny.N, penyebabnya $\mathrm{Ny} . \mathrm{N}$ sebagai 
subjek di karenakan pasien belum bisa mengatasi emosinya selain minum obat. Maka tujuan asuhan keperawatan yang akan di lakukan ialah untuk mengajarkan standar pelaksanaan masalah halusinasi penglihatan pada saat Ny.N mengalami halusinasinya.

\subsection{Rumusan masalah}

Berdasarkan masalah yang telah di paparkan pada latar belakang maka rumusan masalah dalam askep ini yaitu Asuhan keperawatan masalah halusinasi Peglihatan Ny.N, di Yayasan pemenang jiwa

\subsection{Tujuan}

\subsubsection{Tujuan Umum}

Mahasiswa mampu memberikan asuhan keperawatan kepada $\mathrm{Ny} . \mathrm{N}$ dengan gangguan persepsi sensori : halusinasi penglihatan

\subsubsection{Tujuan Khusus}

1. Mahasiswa mampu memahami Pengertian, tanda dan gejala, etiologi, klasifikasi, dan penatalaksanaan dan gangguan persepsi sensori: Halusinasi Penglihatan

2. Mahasiswa mampu melakukan pengkajian pada Ny.N dengan gangguan persepsi sensori: Halusinasi Penglihatan

3. Mahasiswa mampu menegakkan diagnosa keperawatan yang ada pada Ny.N dengan gangguan persepsi sensori: Halusinasi Penglihatan

4. Mahasiswa mampu menetapkan perencanaan keperawatan pada Ny.N dengan gangguan persepsi sensori: Halusinasi Penglihatan

5. Mahasiswa mampu melakukan implementasi keperawatan pada Ny.N dengan gangguan persepsi sensori: Halusinasi Penglihatan

6. Mahasiswa mampu mengevaluasi hasil asuhan keperawatan pada Ny.N dengan gangguan persepsi sensori: Halusinasi Penglihatan

7. Mahasiswa mampu mendokumentasikan asuhan keperawatan yang diberikan pada Ny.N dengan gangguan persepsi sensori: Halusinasi Penglihatan 


\section{BAB 2}

\section{TINJAUAN TEORITIS}

\subsection{Konsep Halusinasi}

\subsubsection{Definisi Halusinasi}

Halusinasi adalah salah satu gejala gangguan jiwa di mana pasien mengalami perubahan sensorik dalam persepsi indra, ketidakmampuan untuk membedakan rangsangan internal (pikiran) dan rangsangan eksternal (dunia luar), adanya persepsi yang salah tentang lingkungan tanpa benda. Halusinasi adalah gangguan penerimaan pancaindra tanpa stimulasi eksternal (halusinasi pendengaran, penglihatan, pengecapan, penciuman, dan perabaan). Halusinasi merupakan salah satu gejala gangguan jiwa pada individu yang ditandai dengan perubahan sensori persepsi yaitu merasakan sensasi palsu berupa suara, penglihatan, pengecapan, perabaan atau penghiduan. Pasien merasakan stimulus yang sebenarnya tidak ada (Emulyani, 2020).

\subsubsection{Etiologi}

Faktor-faktor yang menyebabkan klien gangguan jiwa mengalami halusinasi adalah sebagai berikut (Pardede et al, 2021):

1. Faktor Predisposisi

a. Faktor genetis

Secara genetis, skizofrenia diturunkan melalui kromosomkromosom tertentu. Namun demikian, kromosom ke berapa yang menjadi faktor penentu gangguan ini sampai sekarang masih dalam tahap penelitian. Anak kembar identik memiliki kemungkinan mengalami skizofrenia sebesar 50\% jika salah satunya mengalami skizofrenia, sementara jika dizigote, peluangnya sebesar $15 \%$. Seorang anak yang salah satu orang tuanya mengalami skizofrenia berpeluang $15 \%$ mengalami skizofrenia, sementara bila kedua orang tuanya skizofrenia maka peluangnya menjadi $35 \%$. 


\section{b. Faktor neurobiologis}

Klien skizofrenia mengalami penurunan volume dan fungsi otak yang abnormal. Neurotransmitter juga ditemukan tidak normal, khususnya dopamin, serotonin, dan glutamat.

1) Studi neurotransmitter

Skizofrenia di duga juga disebabkan oleh adanya, ketidakseimbangan neurotransmitter, dopamin berlebihan, tidak seimbang dengan kadar serotonin.

2) Teori virus

Paparan virus influenza pada trimester ketiga kehamilan dapat menjadi faktor predisposisi skizofrenia.

3) Psikologis

Beberapa kondisi psikologis yang menjadi faktor predisposisi skizofrenia antara lain anak yang diperlakukan oleh ibu yang pencemas, terlalu melindungi, dingin, dan tak berperasaan, sementara ayah yang mengambil jarak dengan anaknya.

2. Faktor Presipitasi

1) Berlebihannya proses informasi pada sistem saraf yang menerima dan memproses informasi di thalamus dan frontal otak.

2) Mekanisme penghantaran listrik di syaraf terganggu.

3) Kondisi kesehatan, meliputi : nutrisi kurang, kurang tidur, ketidakseimbangan irama sirkadian, kelelahan, infeksi, obatobat sistem syaraf pusat, kurangnya latihan, hambatan untuk menjangkau pelayanan kesehatan.

4) Lingkungan, meliputi : lingkungan yang memusuhi, krisis masalah di rumah tangga, kehilangan kebebasan hidup, perubahan kebiasaan hidup, pola aktivitas sehari-hari, kesukaran dalam hubungan dengan orang lain, isolasi social, kurangnya dukungan sosial, tekanan kerja, kurang ketrampilan dalam bekerja, stigmatisasi, kemiskinan, ketidakmampuan mendapat pekerjaan. 
5) Sikap/perilaku, meliputi : merasa tidak mampu, harga diri rendah, putus asa, tidak percaya diri, merasa gagal, kehilangan kendali diri, merasa punya kekuatan berlebihan, merasa malang, bertindak tidak seperti orang lain dari segi usia maupun kebudayaan, rendahnya kernampuan sosialisasi, perilaku agresif, ketidakadekuatan pengobatan, ketidakadekuatan penangan gejala.

\subsubsection{Klasifikasi Halusinasi}

Dibawah ini beberapa tipe dari halusinasi (Muttar, 2011)

a. Halusinasi Pendengaran

Mendengar suara kebisingan yang kurang jelas ataupun yang jelas, dimana terkadang suara-suara tersebut seperti mengajak berbicara klien dan kadang memerintah klien untuk melakukan sesuatu yang berbahaya, marah-marah tanpa sebab, mencondongkan telinga ke arah tertentu dan menutup telinga.

b. Halusinasi Penglihatan

Stimulus visual dalam bentuk kilatan atau cahaya, gambar atau bayangan yang rumit dan kompleks, klien menunjukkan ke arah tertentu, ketakutan pada objek yang tidak jelas, bayangan bisa menyenangkan atau menakutkan, melihat hantu/ monster, dan bentuk geometris lainnya.

c. Halusinasi Penciuman

Menghirup seperti sedang membau bau-bauan tertentu seperti bau darah, urine, feses, perfum, atau bau yang lain. Ini sering terjadi pada seseorang pasca serangan store, kejang, atau dimensia.

d. Halusinasi Sentuhan

Klien mengaruk-garuk permukaan kulit, mengatakan ada serangga dipermukaan kulit, merasa seperti tersengat listrik. 


\section{e. Halusinasi Pengecapan}

Klien sering meludah, muntah, merasakan, seperti mengecap darah, urine seperti feses, atau yang lainnya.

\subsubsection{Tanda dan Gejala}

Beberapa tanda dan gejala perilaku halusinasi adalah tersenyum atau tertawa yang tidak sesuai, menggerakkan bibir tanpa suara, bicara sendiri, pergerakan mata cepat, diam, asyik dengan pengalaman sensori, kehilangan kemampuan membedakan halusinasi dan realitas rentang perhatian yang menyempit hanya beberapa detik atau menit, kesukaran berhubungan dengan orang lain, tidak mampu merawat diri (Ayunaningrum, 2012).

Berikut tanda dan gejala Halusinasi Penglihatan (Pardede et al, 2021) :

a. Stimulus penglihatan dalam kilatan cahaya

b. gambar giometris

c. gambar karton dan atau panorama yang luas dan komplek.

d. Penglihatan dapat berupa sesuatu yang menyenangkan /sesuatu yang menakutkan seperti monster.

\subsubsection{Tahap Halusinasi}

Tahap-tahap halusinasi, karakteristik dan perilaku yang ditampilkan oleh klien yang mengalami halusinasi (Oktiviani, 2020) :

\begin{tabular}{|l|l|}
\hline \multicolumn{1}{|c|}{ Tahapan Halusinasi } & \multicolumn{1}{|c|}{ Karakteristik } \\
\hline $\begin{array}{l}\text { Stage I : Sleep disorder } \\
\text { Fase awal seseorang sebelum } \\
\text { muncul halusinasi }\end{array}$ & $\begin{array}{l}\text { Klien merasa banyak masalah, ingin } \\
\text { menghindar dari lingkungan, takut }\end{array}$ \\
diketahui orang lain bahwa dirinya \\
banyak masalah. Masalah makin \\
terasa sulit karna berbagai stressor \\
terakumulasi, misalnya kekasih hamil, \\
terlibat narkoba, dikhianati kekasih, \\
masalah dikampus, drop out, dst. \\
Masalah terasa menekan karena \\
terakumulasi sedangkan support \\
sistem kurang dan persepsi terhadap
\end{tabular}




\begin{tabular}{|c|c|}
\hline & $\begin{array}{l}\text { masalah sangat buruk. Sulit tidur } \\
\text { berlangsung trus-menerus sehingga } \\
\text { terbiasa } \\
\text { menganggap lamunan-lamunan awal } \\
\text { tersebut sebagai pemecah masalah. }\end{array}$ \\
\hline $\begin{array}{l}\text { Stage II: Comforting } \\
\text { Halusinasi secara umum ia } \\
\text { terima sebagai sesuatu yang } \\
\text { alami }\end{array}$ & $\begin{array}{l}\text { Klien mengalami emosi yang } \\
\text { berlanjut seperti adanya perasaan } \\
\text { cemas, kesepian, perasaan berdosa, } \\
\text { ketakutan, dan mencoba memusatkan } \\
\text { pemikiran pada timbulnya kecemasan. } \\
\text { Ia beranggapan bahwa pengalaman } \\
\text { pikiran dan sensorinya dapat dia } \\
\text { kontrol bila kecemasannya diatur, } \\
\text { dalam tahap ini }\end{array}$ \\
\hline $\begin{array}{l}\text { Stage III: Condemning } \\
\text { Secara umum halusinasi sering } \\
\text { mendatangi klien }\end{array}$ & $\begin{array}{l}\text { Pengalaman sensori klien menjadi } \\
\text { sering datang dan mengalami bias. } \\
\text { Klien mulai merasa tidak mampu lagi } \\
\text { mengontrolnya dan mulai berupaya } \\
\text { menjaga jarak antara dirinya dengan } \\
\text { objek yang dipersepsikan klien mulai } \\
\text { menarik diri dari orang lain, dengan } \\
\text { intensitas waktu yang lama. }\end{array}$ \\
\hline $\begin{array}{l}\text { Stage IV: Controlling Severe } \\
\text { Level of Anxiety } \\
\text { Fungsi sensori menjadi tidak } \\
\text { relevan dengan kenyataan }\end{array}$ & $\begin{array}{l}\text { Klien mencoba melawan suara-suara } \\
\text { atau sensori abnormal yang datang. } \\
\text { Klien dapat merasakan kesepian bila } \\
\text { halusinasinya berakhir. Dari sinilah } \\
\text { dimulai fase gangguan psikotik. }\end{array}$ \\
\hline $\begin{array}{l}\text { Stage: V: Conquering Panic } \\
\text { Level of Anxiety } \\
\text { Klien mengalami gangguan } \\
\text { dalam menilai lingkungannya. }\end{array}$ & $\begin{array}{l}\text { Pengalaman sensorinya terganggu. } \\
\text { Klien mulai terasa terancam dengan } \\
\text { datangnya suara-suara terutama bila } \\
\text { klien tidak dapat menuruti ancaman } \\
\text { atau perintah yang ia dengar dari } \\
\text { halusinasinya. Halusinasi dapat } \\
\text { berlangsung selama minimal empat } \\
\text { jam atau seharian bila klien tidak } \\
\text { mendapatkan komunikasi terapeutik. } \\
\text { Terjadi gangguan psikotik berat. }\end{array}$ \\
\hline
\end{tabular}




\subsubsection{Rentang Respon Halusinasi}

Halusinasi merupakan gangguan dari persepsi sensori, waham merupakan gangguan pada isi pikiran. Keduanya merupakan gangguan dari respons neurobiologis. Oleh karenanya secara keseluruhan, rentang respons neurobilogi yang paling adaptif adalah adanya pikiran logis dan terciptanya hubungan sosial yang harmonis. Rentang respons yang paling maladaptif adalah adanya waham, halusinasi, isolasi sosial, dan menarik diri.

Berikut adalah gambaran rentang respons halusinasi (Wulandari, 2018): Adaptif

\section{Maladaptif}

- Pikiran Logis

- Persepsi akurat

- Emosi konsisten dengan pengalaman

- Perilaku cocok

- Hubungan sosial harmonis
- Kadang proses pikir tidak terganggu

- Ilusi

- Emosi tidak stabil

- Perilaku tidak biasa

- Menarik diri
- Gangguan proses berfikir/waham

- Halusinasi

- Kesukaran proses emosi

- Perilaku tidak terorganisasi

- Isolasi sosial

\section{Keterangan:}

1. Respon adaptif adalah respon yang dapat diterima oleh normanorma sosial budaya yang berlaku. Dengan kata lain individu tersebut dalam batas normaljika menghadapi suatu masalah akan dapat memecahkan masalah tersebut.

Respon adaptif :

a. Pikiran logis adalah pandangan yang mengarahkan pada kenyataan

b. Persepsi akurat adalah pandangan yang tepat pada kenyataan

c. Emosi konsisten dengan pengalaman yaitu perasaan yang timbul daripengalaman ahli

d. Perilaku sosial adalah sikap dan tingkah laku yang masih dalam bataskewajaran

e. Hubungan sosial adalah proses suatu interaksi dengan orang lain danlingkungan. 
2. Respon psikososial meliputi

a. Proses pikiran terganggu adalah proses yang menimbulkan gangguan.

b. Ilusi adalah miss interpretasi atau penilaian yang salah tentang penerapan yang benar-benar terjadi (objek nyata) karena rangsangan panca indra.

c. Emosi berlebihan atau berkurang.

d. Perilaku tidak biasa adalah sikap dan tingkah laku yang melebihi batas kewajaran.

e. Menarik diri yaitu percobaan untuk menghindari intraksi dengan orang lain.

3. Respon maladaptif adalah respon individu dalam menyelesaikan masalah yang menyimpang dari norma-norma sosial budaya dan lingkungan, adapun respon maladaptif ini meliputi:

a. Kelainan pikiran adalah keyakinan yang secara kokoh dipertahankan walaupun tidak diyakini oleh orang lain dan bertentangan dengan kenyataan sosial

b. Halusinasi merupakan persepsi sensori yang salah atau persepsieksternal yang tidak realita atau tidak ada

c. Kerusakan proses emosi adalah sesuatu yang timbul dari hati

d. Isolasi sosial adalah kondisi kesendirian yang dialami oleh individu dan diterima sebagai ketentuan oleh orang lain dan sebagai suatu kecelakaan yang negatif mengancam.

\subsubsection{Penatalaksanaan Medis}

Halusinasi merupakan salah satu gejala yang paling sering terjadi pada gangguan Skizofrenia. Dimana Skizofrenia merupakan jenis psikosis, adapun tindakan penatalaksanaan dilakukan dengan berbagai terapi (Oktavia, 2019) : 


\section{Farmakoterapi}

Obat-obatan untuk terapi halusinasi berupa antipsikotik, haloperidol, antiansietas, antidepresan, penstabil mood, antiparkinson, serta stimulan.

\section{Terapi psikososial}

Karakteristikdari halusinasi adalah rusaknya kemampuan untuk membentuk dan mempertahankan hubungan sesama manusia, maka intervensi utama difokuskan untuk membantu klien memasuki dan mempertahankan sosialisasi yang penuh arti dalam kemampuan klien Alternatif :

1) Terapi modalitas

Semua sumber daya di rumah sakit disarankan untuk menggunakan

komunikasi yang terapeutik, termasuk semua (staf administrasi, pembantu kesehatan, mahasiswa, dan petugas instalasi)

2) Terapi kelompok

Terapi kelompok adalah psikoterapi yang dilakukan pada klien bersama-sama dengan jalan aukusi yang diarahkan oleh seseorang yang tertatih

3) Terapi keluarga

Tujuan dari terapi keluarga :

a. Menurunkan konflik kecemasan

b. Meningkatkan kesadaran keluarga terhadap kebutuhan masingmasing keluarga

c. Meningkatkan pertanyaan kritis

d. Menggambarkan hubungan peran yang sesuai dengan tumbuh kembang. Perawat membekali keluarga dengan pendidikan tentang kondisi klien dan kepedulian pada situasi keluarga. 


\subsubsection{Mekanisme Koping}

Mekanisme koping dapat dipengaruhi oleh faktor lingkungan, konsep diri, rasa aman nyaman, pengalaman masa lalu dan tingkat pengetahuan seseorang. Mekanisme koping didefinisikan sebagai strategi untuk memanajemen tingkah laku kepada pemecahan masalah yang paling sederhana dan realistis, berfungsi untuk membebaskan diri dari masalah yang nyata maupun tidak nyata, dan koping merupakan semua usaha secara kognitif dan perilaku untuk mengatasi, mengurangi, dan tahan terhadap tuntutan-tuntutan (Muhith, 2015).

\subsection{Konsep Asuhan Keperawatan}

\subsubsection{Pengkajian Keperawatan}

Menurut Pardede, et al (2021). Bahwa faktor-faktor terjadinya halusinasi meliputi:

1. Faktor predisposisi

Faktor predisposisi atau faktor yang mendukung terjadinya halusinasi adalah :

a. Faktor biologis

Pada keluarga yang melibatkan anak kembar dan anak yang diadopsi menunjukkan peran genetik pada schizophrenia.Kembar identik yang dibesarkan secara terpisah mempunyai angka kejadian schizophrenia lebih tinggi dari pada saudara sekandung yang dibesarkan secara terpisah.

b. Faktor psikologis

Hubungan interpersonal yang tidak harmonis akan mengakibatkan stress dan kecemasan yang berakhir dengan gangguan orientasi realita.

c. Faktor sosial budaya

Stress yang menumpuk awitan schizophrenia dan gangguan psikotik lain, tetapi tidak diyakini sebagai penyebab utama gangguan. 
2. Faktor presipitasi Faktor presipitasi atau faktor pencetus halusinasi menurut Stuart (2014) adalah:

a. Biologis

Stressor biologis yang berhubungan dengan respon neurobiologis maladaptif adalah gangguan dalam komunikasi dan putaran umpan balik otak dan abnormalitas pada mekanisme pintu masuk dalam otak, yang mengakibatkan ketidakmampuan untuk secara selektif menanggapi stimulus.

b. Lingkungan

Ambang toleransi terhadap stres yang ditentukan secara biologis berinteraksi dengan stresor lingkungan untuk menentukan terjadinya gangguan prilaku.

c. Stres sosial / budaya

Stres dan kecemasan akan meningkat apabila terjadi penurunan stabilitas keluarga, terpisahnya dengan orang terpenting atau disingkirkan dari kelompok.

d. Faktor psikologik

Intensitas kecemasan yang ekstrem dan memanjang disertai terbatasnya kemampuan mengatasi masalah dapat menimbulkan perkembangan gangguan sensori persepsi halusinasi.

e. Mekanisme koping

Menurut Stuart (2014) perilaku yang mewakili upaya untuk melindungi pasien dari pengalaman yang menakutkan berhubungan dengan respons neurobiologis maladaptif meliputi : regresi, berhunbungan dengan masalah proses informasi dan upaya untuk mengatasi ansietas, yang menyisakan sedikit energi untuk aktivitas sehari-hari. Proyeksi, sebagai upaya untuk menejlaskan kerancuan persepsi dan menarik diri.

f. Sumber koping

Menurut Stuart (2014) sumber koping individual harus dikaji dengan pemahaman tentang pengaruh gangguan otak pada perilaku. Orang tua harus secara aktif mendidik anak-anak dan 
dewasa muda tentang keterampilan koping karena mereka biasanya tidak hanya belajar dari pengamatan. Disumber keluarga dapat pengetahuan tentang penyakit, finensial yang cukup, faktor ketersediaan waktu dan tenaga serta kemampuan untuk memberikan dukungan secara berkesinambungan.

g. Perilaku halusinasi

Menurut Towsend (2016), batasan karakteristik halusinasi yaitu bicara teratawa sendiri, bersikap seperti memdengar sesuatu, berhenti bicara ditengah - tengah kalimat untuk mendengar sesuatu, disorientasi, pembicaraan kacau dan merusak diri sendiri, orang lain serta lingkungan.

\subsubsection{Diagnosis Keperawatan}

Menurut PPNI (2016) diagnosis keperawatan merupakan suatu penilaian klinis mengenai respon klien terhadap masalah kesehatan atau proses kehidupan yang di alaminya baik yang berlangsung aktual mauapun potensial, diagnosis keperawatan bertujuan untuk mengidentifikasi respon individu klien, keluarga dan komunitas terhadap situasi yang berkaitan dengan kesehatan.

Adapun diagnosis keperawatan yang dapat muncul pada diagnosis utama gangguan perseepsi sensori halusinasi menurut (Sutejo, 2019) adalah:

1) Gangguan Persepsi Sensori: Halusinasi Penglihatan

2) Resiko Perilaku Kekerasan

\subsubsection{Perencanaan Keperawatan}

Perencanaan Keperawatan Rencana tindakan pada keluarga ( Husein,\& Arifin, 2011) adalah;

1. Diskusikan masalah yang dihadap keluarga dalam merawat pasien

2. Berikan penjelasan meliputi : pengertian halusinasi, proses terjadinya halusinasi, jenis halusinasi yang dialami, tanda dan gejala halusinasi, proses terjadinya halusinasi. 
3. Jelaskan dan latih cara merawat anggota keluarga yang mengalami halusinasi : menghardik, minum obat, bercakapcakap, melakukan aktivitas.

4. Diskusikan cara menciptakan lingkungan yang dapat mencegah terjadinya halusinasi.

5. Diskusikan tanda dan gejala kekambuhan

6. Diskusikan pemanfaatan fasilitas pelayanan kesehatan terdekat untuk follow up anggota keluarga dengan halusinasi

Rencana tindakan keperawatan pada klien dengan diagnosa gangguan persepsi sensori halusinasi meliputi pemberian tindakan keperawatan berupa terapi (Sulah, Pratiwi, \& Teguh. 2016) yaitu:

1) Bantu klien mengenal halusinasinya meliputi isi, waktu terjadi halusinasi, isi, frekuensi, perasaan saat terjadi halusinasi respon klien terhadap halusinasi

mengontrol halusinasi dengan cara menghardik,

2) meminum obat secara teratur.

3) Melatih bercakap-cakap dengan orang lain,

4) Menyusun kegiatan terjadwal dan dengan aktifitas

\subsubsection{Implementasi Keperawatan}

Implementasi disesuaikan dengan rencana tindakan keperawatan. Pada situasi nyata sering pelaksanaan jauh berbeda dengan rencana, hal ini terjadi karena perawat belum terbiasa menggunakan rencana tertulis dalam melaksanakan tindakan keperawatan (Pardede et al, 2021). Sebelum melaksanakan tindakan keperawatan yang sudah direncanakan, perawat perlu memvalidasi dengan singkat apakah rencana tindakan masih sesuai dan dibutuhkan klien sesuai dengan kondisinya (here and now). Perawat juga menilai diri sendiri, apakah kemampuan interpersonal, intelektual, tekhnikal sesuai dengan tindakan yang akan dilaksanakan, dinilai kembali apakah aman bagi klien. Setelah semuanya tidak ada hambatan maka tindakan keperawatan boleh dilaksanakan. 
Adapun pelaksanaan tindakan keperawatan jiwa dilakukan berdasarkan Strategi Pelaksanaan (SP) yang sesuai dengan masing-masing masalah utama. Pada masalah gangguan sensori persepsi: halusinasi pendengaran, terdapat 2 jenis SP, yaitu SP Klien dan SP Keluarga. SP klien terbagi menjadi SP 1 (membina hubungan saling percaya, mengidentifikasi halusinasi "jenis, isi, waktu, frekuensi, situasi, perasaan dan respon halusinasi", mengajarkan cara menghardik, memasukan cara menghardik ke dalam jadwal; SP 2 (mengevaluasi SP 1, mengajarkan cara minum obat secara teratur, memasukan ke dalam jadwal); SP 3 (mengevaluasi SP 1 dan SP 2, menganjurkan klien untuk mencari teman bicara); SP 4 (mengevaluasi SP 1, SP 2, dan SP 3, melakukan kegiatan terjadwal).

SP keluarga terbagi menjadi SP 1 (membina hubungan saling percaya, mendiskusikan masalah yang dihadapi keluarga dalam merawat pasien, menjelaskan pengertian, tanda dan gejala helusinasi, jenis halusinasi yang dialami klien beserta proses terjadinya, menjelaskan cara merawat pasien halusinasi); SP 2 (melatih keluarga mempraktekan cara merawat pasien dengan halusinasi, melatih keluarga melakukan cara merawat langsung kepada pasien halusinasi); SP 3 (membantu keluarga membuat jadwal aktivitas di rumah termasuk minum obat (discharge planing), menjelaskan follow up pasien setelah pulang).

Pada saat akan dilaksanakan tindakan keperawatan maka kontrak dengan klien dilaksanakan dengan menjelaskan apa yang akan dikerjakan dan peran serta klien yang diharapkan, dokumentasikan semua tindakan yang telah dilaksanakan serta respon klien (Hafizuddin, 2021). 


\subsubsection{Evaluasi Keperawatan}

PPNI (2019), memaparkan kemampuan klien dapat dievaluasi sesuai dengan yang diharapkan setelah dilakukan tindakan keperawatan berdasarkan kriteria hasil yang telah ditetapkan, yaitu verbalisasi klien melihat bayangan menurun, menarik diri menurun, melamun menurun, curiga menurun, mondar-mandir menurun, konsentrasi membaik, orientasi membaik. 


\section{BAB 3}

\section{TINJAUAN KASUS}

\subsection{Identitas Klien}

Inisial

Umur

Agama

Status

Alamat

Ruang Rawat

Tanggal Pengkajian
: Ny.N

: 68 Tahun

: Kristen

: Belum Menikah

: Sungai Seikambing

: Yayasan Pemenang Jiwa Sumatera

: 04 Maret 2021

\subsection{Alasan Masuk}

Klien Awalnya marah-marah, suka menyendiri, melamun, klien berbicara dan tertawa sendiri, mondar mandir, merasa malu dengan keadaan keluarga nya dan menjauhi teman sebaya nya, selalu menganggap dirinya masih muda dan ketika dia melihat laki-laki dia selalu mengira bahwa itu saudara laki-lakinya. Masalah Keperawatan : Gangguan Sensori Persepsi Halusinasi Penglihatan

\subsection{Faktor Predisposisi}

Klien sebelumnya pernah mengalami gangguan jiwa \pm 42 Tahun yang lalu. Klien, suka menyendiri, melamun, mondar mandir, melihat bayangan tanpa wujud, akhirnya keluarga membawa klien. Keluarga klien tidak ada yang pernah mengalami gangguan jiwa. Hal ini di alami karena dulu kehidupan keluarga nya orang berada lama kelamaan pensiun dan semua harta di kembalikan ke negara sehingga kehidupan keluarga turun drastis, sehingga pasien menjadi malu, menyendiri, depresi, bicara sendiri dan tidak menerima kenyataan.

Masalah Keperawatan : Halusinasi penglihatan 


\subsection{Fisik}

Pada saat dilakukan pemeriksaan fisik pada pasien, pasien tidak memliki pemeriksaan fisik, didapat hasil

1. Tanda Vital $: \mathrm{TD}=120 / 70 \mathrm{mmHg} \mathrm{N}=80 \mathrm{x} / \mathrm{i} \mathrm{S}=36$ OC $\mathrm{RR}=20 \mathrm{x} / \mathrm{i}$

2. Ukur: $\mathrm{TB}=165 \mathrm{~cm} \mathrm{BB}=60 \mathrm{Kg}$

3. Keluhan Fisik : Pada saat dilakukan pengkajian didapatkan bahwa Ny. N tidak mengalami suatu keluhan fisik

\subsection{Psikososial}

\subsubsection{Genogram}

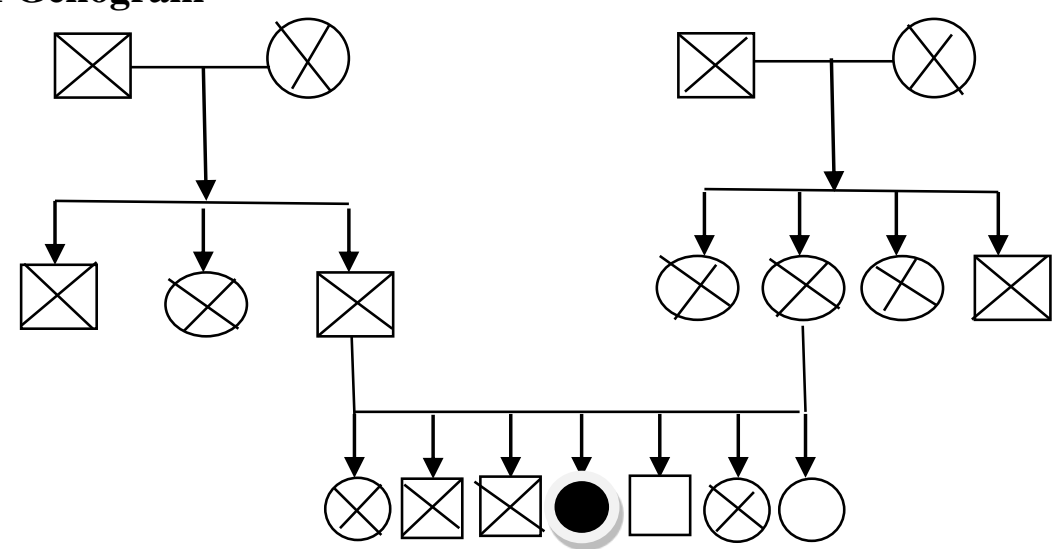

Penjelasan :

Klien merupakan anak ke empat dari 7 bersaudara, klien memiliki 3 saudara laki-laki dan 3 saudara perempuan. Klien belum menikah

Keterangan :

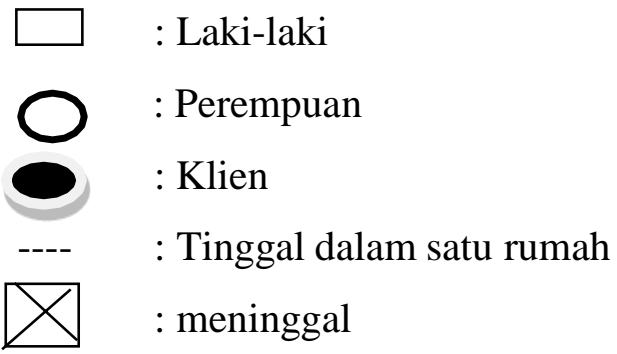

\subsubsection{Konsep Diri}

a. Gambaran Diri : Klien merasa dirinya cantik tanpa ada kecacatan atau kekurangan pada dirinya. 
b. Identitas : Klien mengatakan saya adalah seorang gembala tuhan dan sedang kuliah jurusan gembala tuhan

c. Peran : Selama dirawat pasien berperan sebagai pasien dan sekarang klien tidak bisa bekerja dan beraktivitas seperti orang yang lainnya

d. Ideal diri $\quad$ : Jika saya sembuh nanti saya mau ketemu mama papa saya

e. Harga diri : Saya merasa malu dengan lingkungannya, klien menangis dan merasa dirinya tidak dibutuhkan lagi di keluarganya

Masalah Keperawatan : Isolasi Sosial

\subsubsection{Hubungan Sosial}

a. Orang yang berarti

Pasien mengatakan orang terdekatnya adalah adek kandungnya.

b. Peran serta dalam kegiatan kelompok/masyarakat

Sebelum sakit klien adalah orang yang sangat manja, dia mempunyai asisten rumah tangga yang selalu mempersiapkan segala kebutuhan nya seperti makanan, pakaian sekolah nya. Setelah orangtuanya pensiun dan segala saham dikembalikan ke negara, keadaan keluarga mereka menurun drastis sehingga klien tersebut tidak bisa menerima kenyataan orangtuanya jatuh miskin dan klien menjadi orang yang sangat tertutup dan tidak mau berkomunikasi lagi dengan orang di lingkunganya.

c. Hambatan Berhubungan dengan orang lain :

Klien mengatakan sekarang kondisinya sudah lebih baik, sudah memulai untuk berkomunikasi dengan teman seruangannya 


\subsubsection{Spiritual}

a. Nilai dan Keyakinan : Klien merasa dirinya selalu dilindungi oleh Tuhan, klien selalu beribadah

b. Kegiatan ibadah :Klien selalu melakukan ibadah selama di rawat

\subsubsection{Status Mental}

1. Penampilan : Klien tampak berpakaian seperti biasanya

2. Pembicaraan : Saat berinteraksi dengan perawat nada suara klien rendah, bicara klien lambat dan klien merespon pertanyaan dengan baik

3. Aktivitas Motorik :Aktivitas keseharian klien merasa gelisah dan Klien mengatakan sedih karena sampai saat ini keluarga belum juga datang untuk menjenguknya, terkadang klien terlihat tertawa sendiri seperti melihat bayangan, klien mengatakan melihat bayangan orang tuanya dan adeknya yang datang menjenguknya

Masalah Keperawatan : Halusinasi penglihatan

4. Alam Perasaan : klien mengatakan sedih karena rindu dengan keluarga yang tak kunjung datang menjenguk nya.

5. Afek : afek klien datat, klien menjawab pertanyaan dari perawat

6. Interaksi selama wawancara : selama komunikasi dengan perawat terjadinya kontak mata dan terlihat klien percaya dengan perwata.

7. Persepsi/ Halusinasi : klien mengatakan melihat bayangan orangtua dan adeknya

Masalah Keperawatan: Gangguan Persepsi sensori: Halusinasi Penglihatan 
8. Proses Pikir

:saat di ajak berinteraksi, klien tampak mengulang kata-kata yang sama dan klien banyak bingung

Masalah Keperawatan : Gangguan Persepsi sensori: Halusinasi Penglihatan

9. Isi Pikir $\quad$ : klien tidak memiliki kelainan isi fikir dan waham 10. Tingkat Kesadaran : Tingkat kesadaran klien compos mentis, tidak ditemukan disorientasi waktu, orang dan tempat dibuktikan dengan klien dapat menyebutkan hari Selasa, tanggal, nama perawat suster Mega, dan tempat klien dirawat di yayasan.

11. Memori : daya ingat klien baik

12. Tingkat konsentrasi dan berhitung : klien mampu berhitung dan berkonsentrasi dengan baik

13. Kemampuan penilaian : klien mampu menilai mana yang lebih diutamakan dalam mengambil keputusan

14.

Daya tilik diri : klien merasa bahwa yang dia lihat itu benar

Masalah Keperawatan : Halusinasi Penglihatan

\subsection{Mekanisme Koping}

Klien mampu berbicara dengan orang lain, klien juga suka bernyanyi dan selalu berdoa

\subsection{Masalah Psikososial Dan Lingkungan}

a) Masalah dengan dukungan kelompok, sesifik: Pasien mengatakan mempunyai banyak teman di yayasan pemenang jiwa. .

b) Masalah dengan lingkungan : Klien sering ikut serta kegiatan diyayasan dan berkomunikasi dengan teman 
c) Masalah dengan pendidikan : Klien mengatakan bersekolah sampai SMA dan ingin melanjutkan kuliah ataupun bekerja

d) Masalah dengan pekerjaan : Klien mengatakan pernah gagal dalam pekerjaannya

e) Masalah dengan perumahan : Klien mengatakan tidak ada masalah dengan perumahannya

f) Masalah dengan ekonomi : klien lahir ditengah keluarga berada

g) Masalah dengan pelayanan kesehatan :Klien tidak mengalami masalah dengan pelayanan kesehatan. Namun

\subsection{Kurang Pengetahuan Tentang}

Klien mengatakan kurang tahu tentang keadaaannya saat ini karena klien merasa bayangan yang dilihat itu benar

\subsection{Aspek Medik}

Diagnosa Medis : Skizofrenia Paranoid

TerapiMedik : Resperidon tablet $2 \mathrm{mg} 2 \times 1$

Chlozapine tablet $25 \mathrm{mg} 1 \mathrm{x} 1$

Depakote $250 \mathrm{ml} 1 \mathrm{x} 1$

\subsection{Analisa Data}

\begin{tabular}{|c|c|c|c|}
\hline No & SYMPTOMS & PROBLEM & \\
\hline 1. & $\begin{array}{l}\text { DS : } \\
\text { Klien mengatakan perasaan } \\
\text { saat ini senang dengan } \\
\text { bayangan yang klien lihat, } \\
\text { klien mengatakan senang } \\
\text { karena melihat bayangan orang } \\
\text { tuanya dan adik laki-lakinya } \\
\text { yang datang menjenguk. Klien } \\
\text { mengatakan bayangan lebih }\end{array}$ & $\begin{array}{l}\text { Gangguan persepsi } \\
\text { Halusinasi Penglihatan }\end{array}$ & sensori: \\
\hline
\end{tabular}




\begin{tabular}{|c|c|c|}
\hline & $\begin{array}{l}\text { sering datang saat siang dan } \\
\text { malam hari. } \\
\text { DO: } \\
\text { Saat dikaji kosentrasi klien } \\
\text { kurang, klien mudah beralih } \\
\text { pandangan, klien sering terlihat } \\
\text { melamun melihat ke satu arah } \\
\text { dan tersenyum sendiri, dan } \\
\text { terkadang terlihat sering } \\
\text { mondar-mandir dengan mimik } \\
\text { muka yang cemas. }\end{array}$ & \\
\hline 2. & $\begin{array}{l}\text { DS : } \\
\text { Klien mengatakan saat dirumah } \\
\text { lebih suka berdiam diri dikamar } \\
\text { karena merasa aman dan tidak } \\
\text { ada yang menyakiti } \\
\text { perasaannya, klien juga } \\
\text { mengatakan takut dan tidak } \\
\text { ingin bergabung lama-lama } \\
\text { dengan kelompok karena klien } \\
\text { takut diledek. } \\
\text { DO : } \\
\text { Klien tampak lebih sering } \\
\text { menyendiri, klien tampak hanya } \\
\text { melihat pasien lain dari jauh, } \\
\text { klien jarang berinteraksi dengan } \\
\text { pasien lain dan perawat, kontak } \\
\text { mata klien juga kurang, dan } \\
\text { klien terkadang menolak untuk }\end{array}$ & Isolasi Sosial \\
\hline
\end{tabular}




\begin{tabular}{|l|l|l|}
\hline 3. & $\begin{array}{l}\text { diajak berbincang dengan alasan } \\
\text { mengantuk }\end{array}$ & \\
\hline KS : & Resiko Perilaku Kekerasan \\
memukul teman nya tiba-tiba & \\
karena klien merasa tidak & \\
diperdulikan. & \\
DO: & \\
Wajah klien tampak terlihat & \\
tegang dengan nada suara tinggi & \\
\hline
\end{tabular}

\subsection{Daftar Masalah Keperawatan}

1. Gangguan persepsi sensori: Halusinasi Penglihatan

2. Isolasi Sosial

3. Risiko Perilaku Kekerasan 
3.12. Pohon Masalah

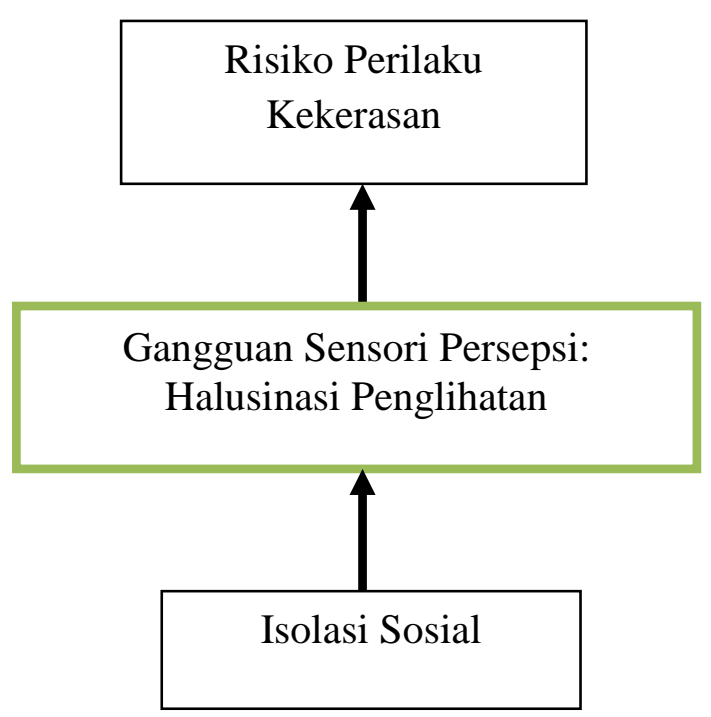

\subsection{Diagnosa Prioritas}

1. Gangguan sensori persepsi : Halusinasi Penglihatan

2. Risiko Perilaku Kekerasan 


\subsection{Intervensi Keperawatan}

\begin{tabular}{|c|c|c|}
\hline NO & DIAGNOSA KEPERAWATAN & Intervensi \\
\hline 1. & $\begin{array}{l}\text { Gangguan persepsi sensori : halusinasi } \\
\text { penglihatan } \\
\text { DS : } \\
\text { - Klien mengatakan perasaan saat ini } \\
\text { senang dengan bayangan yang klien } \\
\text { lihat, } \\
\text { - klien mengatakan senang karena melihat } \\
\text { bayangan orang tuanya dan adik laki- } \\
\text { lakinya yang datang menjenguk. } \\
\text { - Klien mengatakan bayangan lebih sering } \\
\quad \text { datang saat siang dan malam hari. } \\
\text { DO: } \\
\text { - Saat dikaji kosentrasi klien kurang, } \\
\text { - klien mudah beralih pandangan, } \\
\text { - klien sering terlihat melamun melihat ke } \\
\text { satu arah dan tersenyum sendiri } \\
\text { - klien sering mondar-mandir dengan }\end{array}$ & $\begin{array}{l}\text { Sp 1: } \\
\checkmark \quad \text { Mengidentifikasi isi, frekuensi, waktu terjadi, } \\
\text { situasi pencetus, perasaan dan respon } \\
\text { halusinasi. } \\
\checkmark \quad \begin{array}{l}\text { Mengontrol halusinasi dengan cara } \\
\text { menghardik }\end{array} \\
\text { Sp } 2 \text { : mengontrol halusinasidengan makan obat } \\
\quad \text { teratur } \\
\text { Sp } 3 \text { : mengontrol halusinasi dengan bercakap- } \\
\quad \text { cakap denganorang lain } \\
\text { Sp } 4 \text { : mengontrol halusinasi dengan melakukan } \\
\quad \text { kegiatan terjadwal. }\end{array}$ \\
\hline
\end{tabular}




\begin{tabular}{|c|c|c|}
\hline & mimik muka yang cemas. & \\
\hline 2. & $\begin{array}{l}\text { Isolasi sosial : Menarik diri } \\
\text { DS : } \\
\text { - klien jarang mengikuti kegiatan di kelompok } \\
\text { di masyarakat } \\
\text { - klien mengatakan mempunyai hambatan } \\
\text { dengan orang lain } \\
\text { - klien mengatakan lebih suka menyendiri } \\
\text { DO: } \\
\text { - Klien menyendiri } \\
\text { - Klien tidak mau berinteraksi dengan orang } \\
\text { lain } \\
\text { - Klien jarang berkumpul dengan orang lain }\end{array}$ & $\begin{array}{l}\text { Sp } 1 \text { : menjelaskan keuntungan dan kerugian } \\
\text { mempunyai teman } \\
\text { Sp } 2 \text { : melatih klien berkenalan dengan } 2 \text { orang atau } \\
\\
\text { lebih } \\
\text { Sp } 3 \text { : melatih bercakap-cakap sambil melakukan } \\
\text { kegiatan harian } \\
\text { Sp } 4 \text { :melatih berbicara sosial meminta sesuatu, } \\
\text { berbelanja dan sebagainya }\end{array}$ \\
\hline 3 & $\begin{array}{l}\text { Resiko perilaku kekerasan } \\
\text { DS : } \\
\text { Klien mengatakan pernah memukul teman } \\
\text { nya tiba-tiba karena klien merasa tidak } \\
\text { diperdulikan. }\end{array}$ & $\begin{aligned} & \text { Sp } 1 \text { : } \text { Mengontrol perilaku kekerasan dengan : } \\
& \text { - Ajarkan teknik relaksasi nafas dalam } \\
& \text { - Pukul kasur bantal } \\
& \text { Sp } 2 \text { : Mengontrol perilaku kekerasan dengan cara } \text { minum obat secara teratur } \\
& \text { Sp } 3 \text { : Komunikasi secara verbal: Asertif/ bicara }\end{aligned}$ \\
\hline
\end{tabular}


DO:

Wajah klien tampak terlihat tegang dengan nada suara tinggi baik-baik

Sp 4 : Spritual 


\subsection{IMPLEMENTASI DAN EVALUASI KEPERAWATAN}

\begin{tabular}{|c|c|c|}
\hline HARI/TGL & IMPLEMENTASI KEPERAWATAN & EVALUASI (SOAP \\
\hline $\begin{array}{l}\text { Jumat, } \\
\text { 05/03/2021 } \\
\text { Pukul 10.00 WIB }\end{array}$ & 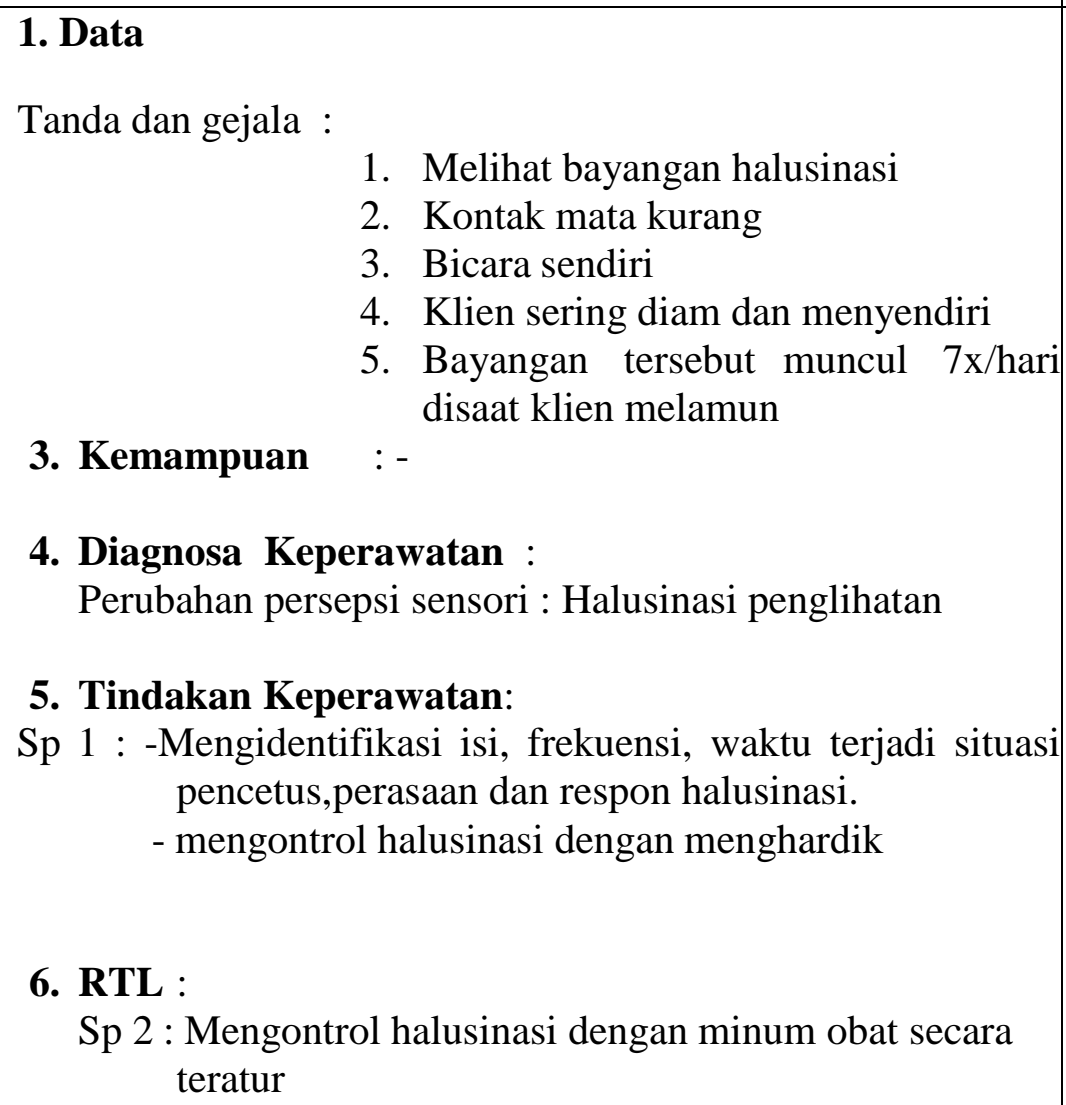 & $\begin{array}{l}\text { S: Klien mengatakan merasa senang } \\
\text { O: } \\
\text { - Klien mampu mengenal halusinasinya dengan } \\
\text { menghardik } \\
\text { A: Perubahan persepsi sensori : Halusinasi } \\
\text { penglihatan }(+) \\
\text { P: } \\
\text { - Melatih mengontrol halusinasi dengan } \\
\text { menghardik } 3 \times 1 \text {. } \\
\text { - Minum obat secara teratur } 2 \times 1\end{array}$ \\
\hline
\end{tabular}




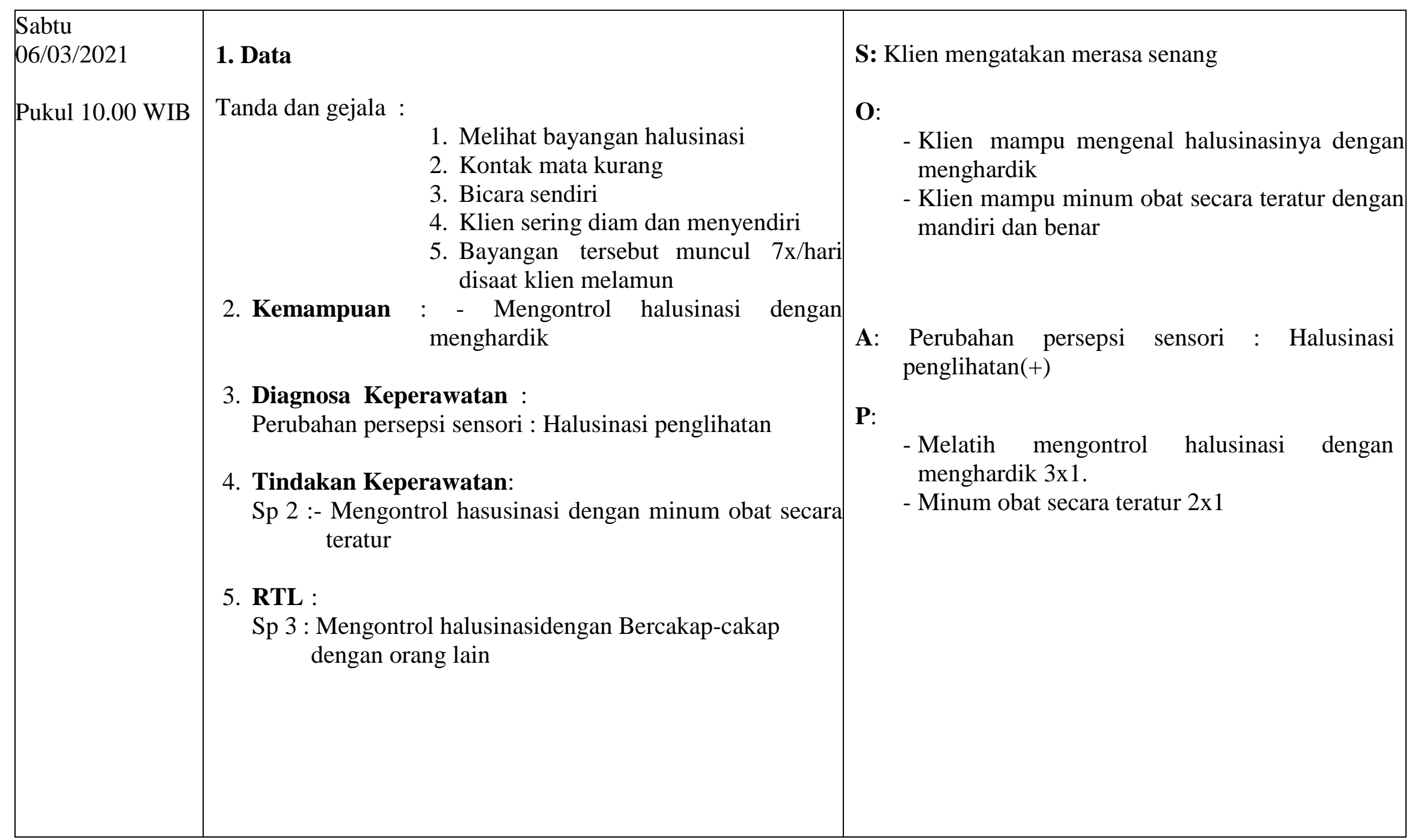




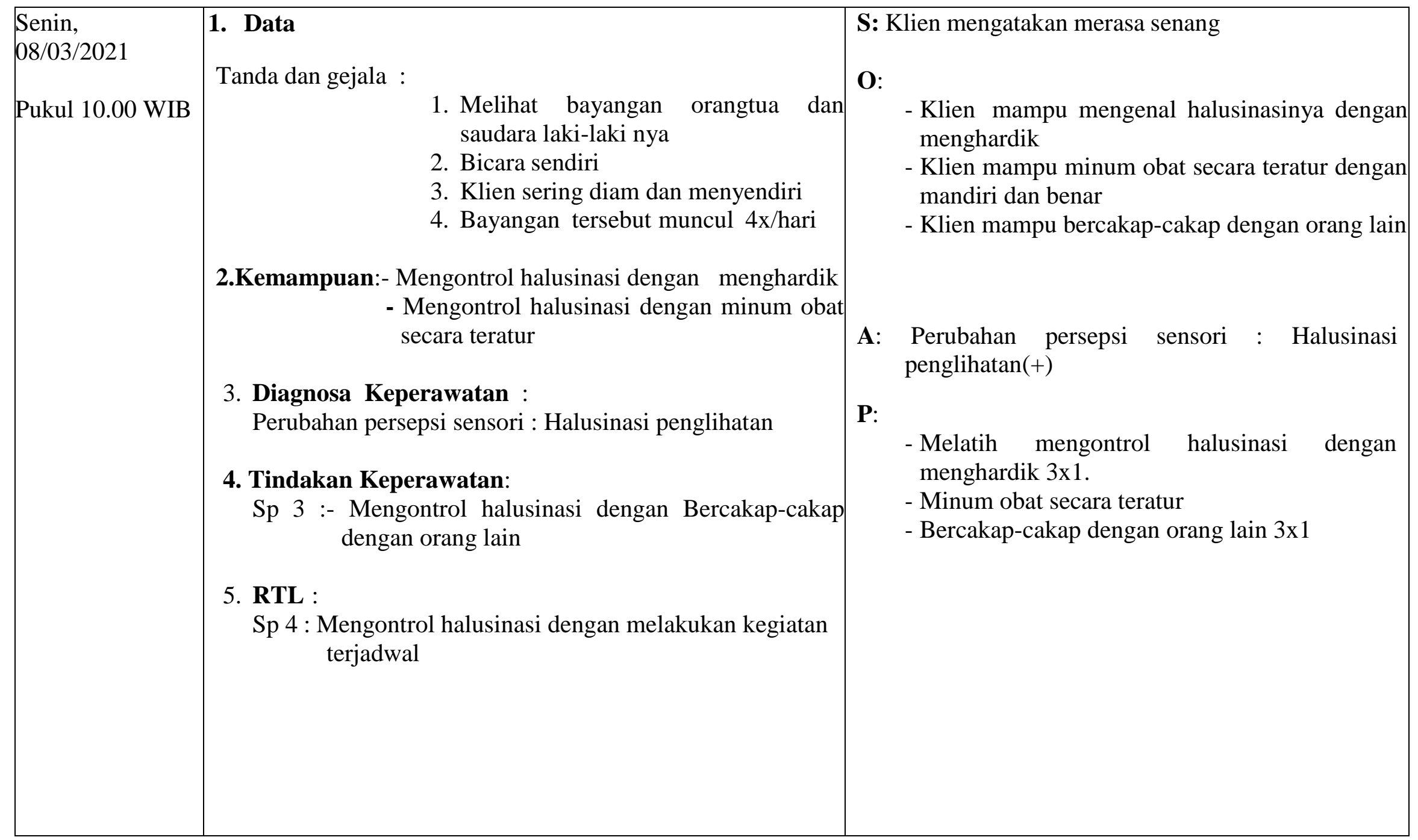




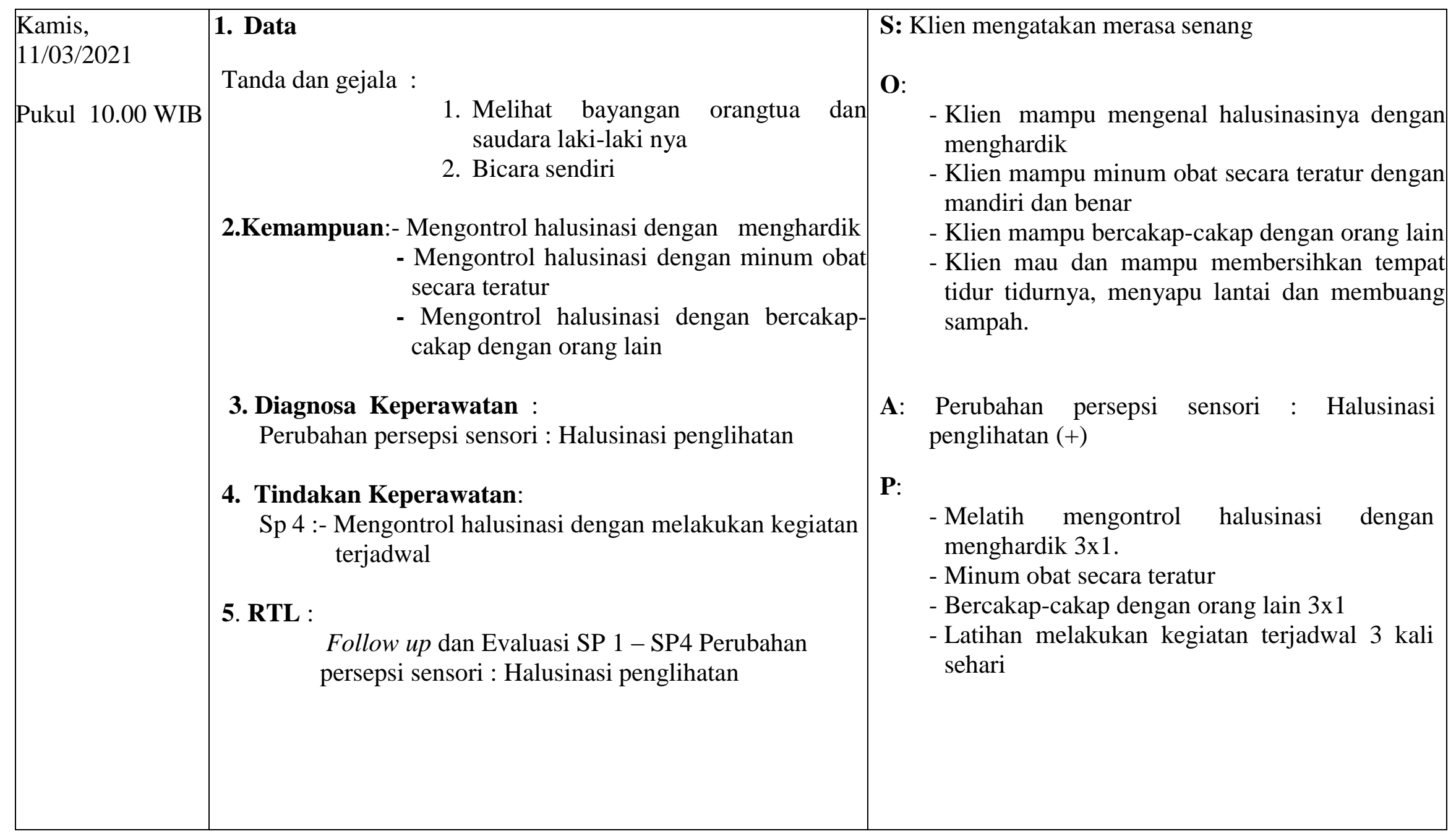




\begin{tabular}{|c|c|c|}
\hline HARI/TGL & IMPLEMENTASI KEPERAWATAN & EVALUASI (SOAP \\
\hline $\begin{array}{l}\text { Rabu, } \\
16 / 03 / 2021 \\
\text { Pukul } \\
10.00 \text { WIB }\end{array}$ & $\begin{array}{l}\text { 1. Data: } \\
\text { Tanda dan gejala : mudah marah-marah, mudah } \\
\text { tersinggung,tatapan sinis, ,suka menyendiri, merasa tidak } \\
\text { dihargai } \\
\text { 2. Diagnosa Keperawatan } \\
\text { Risiko Perilaku Kekerasan } \\
\text { 3. Tindakan keperawatan: } \\
\text { Sp } 1 \text { Risiko Perilaku Kekerasan: } \\
\text { - Mengidentifikasi penyebab risiko perilaku kekerasan } \\
\text { yaitu jika kemauan klien tidak dituruti } \\
\text {-Mengidentifikasi tanda dan gejala risiko perilaku } \\
\text { kekerasan yaitu klien marah, mengamuk tanpa jelas, } \\
\text { merusak barang-barang, dan cenderung melukai orang } \\
\text { lain } \\
\text {-Menyebutkan cara mengontrol risiko perilaku kekerasan } \\
\text { adalah dengan latihan fisik } 1 \text { : tarik napas dalam } \\
\text { latihan fisik } 2 \text { : pukul kasur bantal } \\
\text { - Membantu klien latihan tarik napas dalam dan pukul } \\
\text { kasur bantal. } \\
\text { 4. RTL: } \\
\text { Sp2 Risiko Perilaku Kekerasan: } \\
\text { - Mengontrolrisiko perilaku kekerasan dengan minum }\end{array}$ & $\begin{array}{l}\text { S : antusias dan bersemangat } \\
\text { O : } \\
\text { - Klien mampu melakukan latihan fisik tarik nafas } \\
\quad \text { dalam dengan mandiri } \\
\text { - Klien mampu pukul kasur bantal dengan mandiri } \\
\text { A : Risiko Perilaku kekerasan (+) } \\
\text { P : Latihan fisik: } \\
\quad \text { - Tarik nafas dalam 1x/ hari } \\
\text { - Pukul kasur bantal 1x/ hari }\end{array}$ \\
\hline
\end{tabular}




\begin{tabular}{|c|c|c|}
\hline & obat secara teratur & \\
\hline $\begin{array}{l}\text { Jumat, } \\
19 / 03 / 2021 \\
\text { Pukul } \\
10.00 \text { WIB }\end{array}$ & $\begin{array}{l}\text { 1. Data : } \\
\text { Tanda dan gejala : mudah marah-marah, mudah } \\
\text { tersinggung,tatapan sinis, merasa tidak dihargai } \\
\text { Kemampuan : berjualan depan rumah } \\
\text { 2. Diagnosa Keperawatan } \\
\text { Risiko Perilaku Kekerasan } \\
\text { 3. Tindakan keperawatan: } \\
\text { Sp } 2 \text { Risiko Perilaku Kekerasan } \\
\text { 1.Mengevaluasi kemampuan klienuntuk tarik nafas } \\
\quad \text { dalam dan pukul kasur bantal } \\
\text { 2. Memberikan informasi tentang penggunaan obat } \\
\text { 4.RTL: } \\
\text { Sp } 3 \text { Risiko Perilaku Kekerasan } \\
\text { - Komunikasi secara verbal:Asertif/bicara baik-baik. }\end{array}$ & 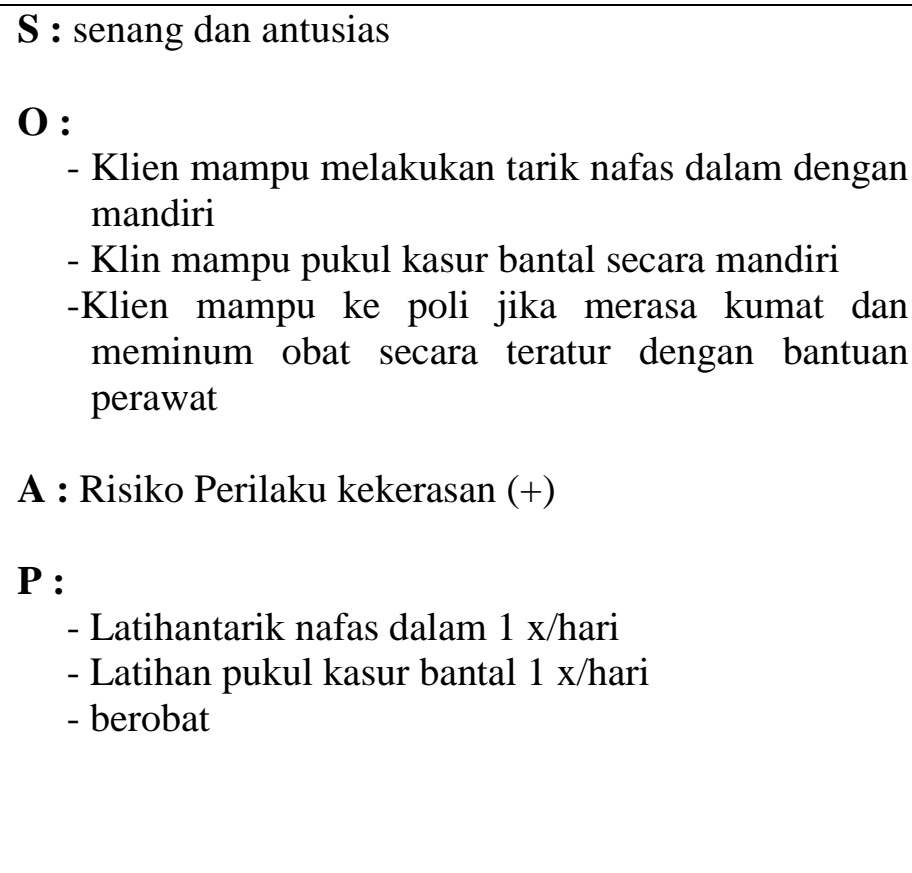 \\
\hline $\begin{array}{l}\text { Senin, } \\
22 / 03 / 2021 \\
\text { Pukul } \\
10.00 \text { WIB }\end{array}$ & $\begin{array}{l}\text { 1. Data : } \\
\text { Tanda dan gejala : mudah marah-marah, mudah } \\
\text { tersinggung,tatapan sinis, merasa tidak dihargai } \\
\text { Kemampuan : berjualan }\end{array}$ & $\begin{array}{l}\text { S : senang } \\
\text { O : } \\
\text { - Klien mampu melakukan komunikasi secara } \\
\quad \text { verbal : asertif/bicara baik-baikdengan } \\
\text { motivasi }\end{array}$ \\
\hline
\end{tabular}




\begin{tabular}{|c|c|c|}
\hline & $\begin{array}{l}\text { 2. Diagnosa Keperawatan: } \\
\text { Risiko Perilaku Kekerasan } \\
\text { 3. Tindakan keperawatan: } \\
\text { Sp } 3 \text { Risiko Perilaku Kekerasan } \\
\text {-Mengevaluasi kemampuan klien untuk tarik nafas dalam } \\
\quad \text { dan pukul kasur bantal } \\
\text { - Minum obat } \\
\text { - Komunikasi secara verbal : asertif/bicara baik-baik } \\
\text { 4.RTL: } \\
\text { Sp } 4 \text { Risiko Perilaku Kekerasan: } \\
\text { - Spritual : Beribadah }\end{array}$ & $\begin{array}{l}\text { A : Risiko Perilaku kekerasan }(+) \\
\text { P : } \\
\text { - Latihantarik nafas dalam dan pukul kasur bantal } \\
\text { 1x/hari } \\
\text { - Berobat } \\
\text { - Klien melakukan komunikasi secara verbal : } \\
\text { asertif/bicara baik-baik }\end{array}$ \\
\hline $\begin{array}{l}\text { Kamis, } \\
25 / 03 / 2021 \\
\text { Pukul } \\
10.00 \text { WIB }\end{array}$ & $\begin{array}{l}\text { 1. Data : } \\
\text { Tanda dan gejala : mudah marah-marah, mudah } \\
\text { tersinggung,tatapan sinis, merasa tidak dihargai } \\
\text { Kemampuan : berjualan } \\
\text { 2. Diagnosa Keperawatan: } \\
\text { Risiko Perilaku Kekerasan } \\
\text { 3.Tindakan keperawatan: } \\
\text { Sp } 4 \text { Risiko Perilaku Kekerasan } \\
\text {-Mengevaluasi kemampuan klien dalam tarik nafas dalam } \\
\text { dan pukul kasur bantal, minum obat secara teratur dan }\end{array}$ & $\begin{array}{l}\text { S : senang } \\
\text { O : } \\
\text { - Klien mampu melaksanakan kegiatan ibadah } \\
\text { dengan baik misalnya Sholat } \\
\text { A : } \\
\text { Pisiko perilaku kekerasan (+) } \\
\text { P: } \\
\quad \text { Latihan tarik nafas dalam dan pukul kasur bantal } \\
\text { 2x/hari } \\
\text { - Berobat } \\
\text { - Latihan melakukan komunikasi secara verbal : } \\
\text { asertif/bicara baik-baik }\end{array}$ \\
\hline
\end{tabular}




\begin{tabular}{|l|l|l|}
\hline $\begin{array}{l}\text { bicara baik-baik. } \\
\text { - Melatih klien untuk melaksanakan kegiatan spiritual } \\
\text { yang sudah diatur. }\end{array}$ & $\begin{array}{c}\text { - Latihan klien untuk melaksanakan kegiatan } \\
\text { spiritual yang sudah diatur. }\end{array}$ \\
$\begin{array}{l}\text { RTL : } \\
\text { Risiko Perilaku Kekerasan : Follow up dan evaluasi SP 1-4 } \\
\text { risiko Perilaku Kekerasan }\end{array}$ & \\
\hline
\end{tabular}




\section{BAB 4}

\section{PEMBAHASAN}

Setelah penulis melaksanakan asuhan keperawat kepada Ny.N dengan gangguan sensori persepsi: halusinasi penglihatan di Yayasan Pemenang Jiwa, , maka penulis pada BAB ini akan membahasan kesenjangan antara teoritis dengan tinjauan kasus. Pembahasan dimulai melalui tahapan proses keperawatan yaitu pengkajian, diagnosa keparawatan, perencanaan, pelaksanaan dan evaluasi.

\subsection{Pengkajian}

Pada pembahasan ini diuraikan tentang hasil pelaksanaan tindakan keperawatan dengan pemberian terapi generalis pada klien halusinasi pendengaran. Pembahasan menyangkut analisis hasil penerapan terapi generalis terhadap masalah keperawatan halusinasi pendengaran. Tindakan keperawatan didasarkan pada pengkajian dan diagnosis keperawatan yang terdiri dari tindakan generalis yang dijabarkan sebagai berikut. Tahap pengkajian pada klien halusinasi dilakukan interaksi perawat-klienmelalui komunikasi terapeutik untuk mengumpulkan data dan informasi tentang status kesehatan klien. Pada tahap ini terjadi proses interaksi manusia, komunikasi, transaksi dengan peran yang ada pada perawat sebagaimana konsep tentang manusia yang bisa dipengaruhi dengan adanya proses interpersonal.

Selama pengkajian dilakukan pengumpulan data dari beberapa sumber, yaitu dari pasien dan tenaga kesehatan di ruangan. Penulis mendapat sedikit kesulitan dalam menyimpulkan data karena keluarga pasien jarang mengunjungi pasien di rumah sakit jiwa. Maka penulis melakukan pendekatan kepada pasien melalui komunikasi terapeutik yang lebih terbuka membantu pasien untuk memecahkan perasaannya dan juga melakukan observasi kepada pasien. Adapun upaya tersebut yaitu:

a. Melakukan pendekatan dan membina hubungan saling percaya diri pada klien agar klien lebih terbuka dan lebih percaya dengan menggunakan perasaan.

b. Mengadakan pengkajian klien dengan wawancara

c. Mengadakan pengkajian dengan cara membaca status, melihat buku rawatan dan bertanya kepada pegawai. 
Dalam pengkajian ini, penulis menemukan kesenjangan karena ditemukan. Pada kasus $\mathrm{Ny} . \mathrm{N}$, klien melihat bayangan yang mengganggu nya sehingga $\mathrm{Ny} . \mathrm{N}$ terlihat sering berbicara sendiri dan marah sendiri yang membuat Ny.N gelisah. Gejala gejala yang muncul tersebut tidak semua mencakup dengan yang ada di teori klinis dari halusinasi (Keliat dkk, 2014). Akan tetapi terdapat faktor predisposisi maupun presipitasi yang menyebabkan kekambuhan penyakit yang dialami oleh Ny.N.

Tindakan keperawatan terapi generalis yang dilakukan pada $\mathrm{Ny}$. $\mathrm{N}$ adalah strategi pertemuan pertama sampai pertemuan empat. Strategi pertemuan pertama meliputi mengidentifikasi isi, frekuensi, jenis, dan respon klien terhadap halusinasi serta melatih cara menghardik halusinasi. Strategi pertemuan kedua yang dilakukan pada Ny. $\mathrm{N}$ meliputi melatih cara mengendalikan dengan bercakap-cakap kepada orang lain. Strategi pertemuan yang ketiga adalah menyusun jadwal kegiatan bersama-sama dengan klien. Strategi pertemuan keempat adalah mengajarkan dan melatih Ny. N cara minum obat yang teratur.

\subsection{Diagnosa Keperawatan}

Pada Teori Halusinasi dalam NANDA (2017), diagnosa keperawatan yang muncul sebanyak 3 diagnosa keperawatan yang meliputi :

1. Isolasi sosial

2. Halusinasi

3. Risiko perilaku kekerasan

\subsection{Implementasi}

Pada tahap implementasi, penulis mengatasi masalah keperawatan yakni: diagnosa keperawatan halusinasi penglihatan dan risiko perilaku kekerasan. Pada diagnosa keperawatan gangguan persepsi sensori halusinasi penglihatan dilakukan strategi pertemuan yaitu mengidentifikasi isi, frekuensi, waktu terjadi, perasaan, respon halusinasi. Kemudian strategi pertemuan yang dilakukan yaitu latihan mengontrol halusinasi dengan cara menghardik. Strategi pertemuan yang kedua yaitu anjurkan minum obat secara teratur, strategi pertemuan yang ke tiga yaitu latihan dengan cara bercakap-cakap pada saat aktivitas dan latihan strategi pertemuan ke empat yaitu melatih klien melakukan semua jadwal kegiatan. Untuk melakukan implementsi pada keluarga, pada tahap-tahap diagnosa tidak dapat dilaksanakan karena penulis tidak 
pernah berjumpa dengan keluarga klien (keluarga tidak pernah berkunjung).

\subsection{Evaluasi}

Pada tinjauan teoritis evaluasi yang diharapkan adalah: Pasien mempercayai perawat sebagai terapis, pasien menyadari bahwa yang dialaminya tidak ada objeknya, dapat mengidentifikaasi halusinasi, dapat mengendalikan halusinasi melalui mengahardik, latihan bercakap-cakap, melakukan aktivitas serta menggunakan obat secara teratur. Pada tinjauan kasus evaluasi yang didapatkan adalah: Klien mampumengontrol dan mengidentifikasi halusinasi, Klien mampu melakukan latihanbercakap-cakap dengan orang lain, Klien mampu melaksanakan jadwal yang telah dibuat bersama, Klien mampu memahami penggunaan obat yang benar: 5 benar. Selain itu, dapat dilihat dari setiap evalusi yang dilakukan pada asuhan keperawatan, dimana terjadi penurunan gejala yang dialami oleh $\mathrm{Ny}$. $\mathrm{N}$ dari hari kehari selama proses interaksi. 


\section{BAB 5}

\section{PENUTUP}

\subsection{Kesimpulan}

Proses keperawatan merupakan metode ilmiah dalam menjalankan proses keperawatan dan menyelesaikan masalah secara sistematis yang digunakan oleh perawat dan peserta didik keperawatan. Penerapan keperawatan dapat meningkatkan otonomi, percaya diri, cara berfikir yang logis, ilmiah, sistematis dan memperlihatkan tanggung jawab dan tanggung gugat serta pengembangan diri perawat. Disamping itu klien dapat melaksanakan mutu pelayanan keperawatan yang baik khusus nya pada klien halusinasi, maka dapatdi ambil ksimpulan sebagai berikut:

1. Pengkajian yang dilaksanakan tidak banyak berbeda dengan pengkajian teoritis maupun penulis tidak mendapat kesulitan dalam pengkajian klien.

2. Dalam usaha mengatasi masalah yang dihadapi klien penulis menyusun tindakan keperawatan sesuai dengan teoritis begitu juga dengan SP.

3. Dalam pelaksanaan tindakan keperawatan disesuaikan dengan perencanaan dapat dilaksanakan walaupun belum optimal.

4. Pada tahap evaluasi terhadap tindakan keperawatan masalah yang dihadapi klien tidak teratasi semua sesuai dengan masalah klien

\subsection{Saran}

1. Bagi Perawat

Diharapkan dapat menerapkan komunikasi terapeutik dalam pelaksanaan strategi pertemuan 1-4 pada klien dengan halusinasi sehingga dapat mempercepat proses pemulihan klien.

\section{Bagi Yayasan}

Laporan ini diharapkan dapat menjadai acuan dan referensi dalam memberikan asuhan keperawatan pada klien dengan halusinasipenglihatan 


\section{DAFTAR PUSTAKA}

Aji, W. M. H. (2019). Asuhan Keperawatan Orang Dengan Gangguan Jiwa Halusinasi Dengan Dalam Mengontrol Halusinasi. https://doi.org/10.31219/osf.io/n9dgs

Ayunaningrum, T. A. (2012). Asuhan Keperawatan Pada Tn. H Dengan Perubahan Persepsi Sensori Halusinasi Pendengaran Di Ruang Sena Rumah Sakit Jiwa Daerah Surakarta (Doctoral dissertation, Universitas Muhammadiyah Surakrta). http://eprints.ums.ac.id/id/eprint/20513

Daulay, W., Wahyuni, S. E., \& Nasution, M. L. (2020). Pemberdayaan Keluarga Dalam Upaya Deteksi Dini Gangguan Jiwa Di Masyarakat. Jurnal Abdidas, 1(6), 812-816. https://doi.org/10.31004/abdidas.v1i6.169

Emulyani, E. (2020). Pengaruh Terapi Zikir Terhadap Penurunan Tanda Dan Gejala Halusinasi Pada Pasien Halusinasi. Health Care: Jurnal Kesehatan, 9(1), 17-25. https://doi.org/10.36763/healthcare.v9i1.60

Erliyani, E. (2019). Gambaran Strategi Koping Pada Pasien Dengan Gangguan Persepsi Sensori Halusinasi: Pendengaran (Doctoral dissertation, University of Muhammadiyah Malang). http://eprints.umm.ac.id/id/eprint/49941

Hafizuddin, D. (2021, March 22). Mental Nursing Care on Mr. A With Hearing Hallucination Problems. https://doi.org/10.31219/osf.io/r3pqu

Husein, A. N., \& Arifin, S. (2011). Gambaran Distribusi Penderita Gangguan Jiwa Di Wilayah Banjarmasin Dan Banjarbaru. Berkala Kedokteran, 9 (2), 199-209. http://dx.doi.org/10.20527/jbk.v9i2.950

Keliat B, dkk. (2014). Proses Keperawatan Jiwa Edisi II. Jakarta : EGC.

Muhith. A. (2015). Pendidikan Keperawatan Jiwa. Yogyakarta : CV Andi Offest

Muttar, M. (2011). Hubungan Dukungan Keluarga Terhadap Kesembuhan Klien Gangguan Halusinasi di Rumah Sakit Khusus Daerah (RSKD) Provinsi Sulawesi Selatan. Skripsi.

Oktavia, D. (2019). Pemberian Terpi Religius Dzikir Dalam Asuhan Keperawatan Pada Nn. A Dengan Masalah Gangguan Persepsi Sensori: Halusinasi Pendengarandi Ruang Rawat Inap Wisma Flamboyan Rsj. Prof. Hb. Saanin Padang. Skripsi. Program Studi Profesi Ners Stikes Perintis

Padang http://repo.stikesperintis.ac.id/899/1/2\%20DESI\%20OKTAVIA.pdf 
Oktiviani, D. P. (2020). Asuhan Keperawatan Jiwa Pada Tn. K dengan masalah Gangguan Persepsi Sensori: Halusinasi Pendengaran di Ruang Rokan Rumah Sakit Jiwa Tampan (Doctoral dissertation, Poltekkes Kemenkes Riau). .http://repository.pkr.ac.id/id/eprint/498

Pardede, J. A. (2019). The Effects Acceptance and Aommitment Therapy and Health Education Adherence to Symptoms, Ability to Accept and Commit to Treatment and Compliance in Hallucinations Clients Mental Hospital of Medan, North Sumatra. J Psychol Psychiatry Stud, 1, 30-35.

Pardede, J. A. (2020). Family Burden Related to Coping when Treating Hallucination Patients. Jurnal Ilmu Keperawatan Jiwa, 3(4), 453-460. http://dx.doi.org/10.32584/jikj.v3i4.671

Pardede, J. A., \& Siregar, R. A. (2016). Pendidikan Kesehatan Kepatuhan Minum Obat Terhadap Perubahan Gejala Halusinasi Pada Klienskizofrenia. Mental Health, 3(1).

Pardede, J. A., Harjuliska, H., \& Ramadia, A. (2021). Self-Efficacy dan Peran Keluarga Berhubungan dengan Frekuensi Kekambuhan Pasien Skizofrenia. Jurnal Ilmu Keperawatan Jiwa, 4(1), 57-66. http://dx.doi.org/10.32584/jikj.v4i1.846

Pardede, J. A., Irwan, F., Hulu, E. P., Manalu, L. W., Sitanggang, R., \& Waruwu, J. F. A. P. (2021). Asuhan keperawatan Jiwa Dengan Masalah Halusinasi. 10.31219/osf.io/fdqzn

PPNI. (2016). Standar Diagnosis Keperawatan Indonesia: Definisi dan Indikator Diagnostik. Jakarta: Dewan pengurus pusat PPNI.

PPNI. (2019). Standar Luaran Keperawatan Indonesia: Definisi dan Kriteria Hasil Keperawatan. Jakarta: Dewan pengurus pusat PPNI.

Prakoso, A. D., \& Herliawati, H. (2020). Aplikasi Keperawatan Jiwa Pada Pasien Halusinasi Pendengaran Dan Penglihatan Dengan Terapi Psikoreligius Di Rsj. Ernaldi Bahar Palembang Provinsi Sumatra Selatan (Doctoral dissertation, Sriwijaya University). http://repository.unsri.ac.id/id/eprint/30248

Stuart, G. W. (2014). Buku Saku Keperawatan Jiwa . Edisi 5. Jakarta. EGC.

Sutejo. (2019). Keperawatan Kesehatan Jiwa: Prinsip dan Praktik Asuhan Keperawatan Jiwa. Yogyakarta: Pustaka Baru Press.

Sulahyuningsih, E., Pratiwi, A., \& Teguh, S. (2016). Pengalaman Perawat Dalam Mengimplementasikan Strategi Pelaksanaan (Sp) Tindakan Keperawatan Pada Pasien Halusinasi Di Rumah Sakit Jiwa Daerah 
Surakarta(Doctoral dissertation, Universitas Muhammadiyah Surakarta). http://eprints.ums.ac.id/id/eprint/40858

Townsend, M. C, (2016) ,Psychiatric Mental Healt Nursing : Concepts of Care in Evidence-BasedPractice(6th ed.), Philadelphia : F.A. Davis.

Wulandari, T. (2018). Pengaruh Pendidikan Kesehatan Terhadap Perubahan Tingkat Kemampuan Keluarga Dalam Perawatan Halusinasi Di Wilayah Kerja Puskesmas Geger Kabupaten Madiun. Skripsi. Program Studi Keperawatan Stikes Bhakti Husada Mulia Madiun. http://repository.stikes-bhm.ac.id/id/eprint/282 